\title{
SENGKETA TANAH EKS KERAJAAN DI KOTAWARINGIN BARAT PROVINSI KALIMANTAN TENGAH
}

\author{
IGA Gangga Santi Dewi \\ Fakultas Hukum Universitas Diponegoro \\ J1. Prof. Soedarto, SH Tembalang, Semarang \\ ganggasanti@yahoo.com
}

\begin{abstract}
Conflicts that ended in court disputes often occurred in the former Kotaringin Kingdom related to the former kingdom lands. Phenomenon of substantive injustice related to former kingdom land policy in the Dictum Fourth letter A UUPA which abolishes former kingdom land and shifts to the State, is an injustice felt by former kingdom parties. Research with the Socio Legal approach with social science methods and theories about law. This research was focused on looking at the facts of the conflict that ended in court disputes and the solution to prevent the disputes of former kingdom land in Kotawaringin Barat.
\end{abstract}

Keywords: Disputes; Former Kingdom Land; UUPA

\begin{abstract}
Abstrak
Konflik yang berakhir sengketa di Pengadilan banyak terjadi di eks Kerajaan Kotaringin terkait tanah-tanah eks kerajaan. Fenomena ketidakadilan substantif terkait kebijakan tanah eks kerajaan dalam Diktum Keempat huruf A UUPA yang menghapuskan tanah eks kerajaan dan beralih kepada Negara, merupakan ketidakadilan yang dirasakan oleh pihak eks kerajaan. Penelitian dengan pendekatan Socio Legal dengan metode dan teori ilmu sosial tentang hukum. Penelitian ini difokuskan dengan melihat fakta konflik yang berakhir sengketa di pengadilan dan solusi untuk mencegah terjadi sengketa tanah eks kerajaan di Kotawaringin Barat.
\end{abstract}

Kata Kunci : Sengketa; Tanah Eks Kerajaan; UUPA

\section{A. Pendahuluan}

\section{Latar belakang Permasalahan} Pasal 33 ayat (3) UUD NRI 1945 menyebutkan bahwa: "Bumi dan air dan kekayaan alam yang terkandung di dalamnya dikuasai oleh negara dan dipergunakan untuk sebesar-besar kemakmuran rakyat". Berdasarkan kewenangan negara dengan hak menguasai negara (HMN) tersebut, maka negara dapat menentukan tanah-tanah mana yang boleh dimiliki oleh perorangan maupun badan hukum dan tanah-tanah mana yang tidak boleh dimiliki baik oleh perorangan atau badan hukum dan tanah untuk kepentingan umum. Oleh karena itu, dalam hal penghapusan tanah hak menjadi tanah negara, maka negara harus memperhatikan hak-hak warga negaranya yang telah diatur oleh Konstitusi UUD NRI 1945 dan peraturan perundang-undangan yang berlaku. Undang-Undang No. 5 Tahun 1960 tentang Peraturan Dasar Pokok-Pokok Agraria (L.N Tahun 1960 No. 104, TLN No. 2043), selanjutnya disebut UUPA, adalah salah satu landasan hukum bagi semua kebijakan pertanahan di Indonesia.

Berbagai konflik yang berakhir sengketa di Pengadilan dan tindak kekerasan secara komunal banyak terjadi di eks Kerajaan Kotawaringin Barat terkait tanahtanah eks kerajaan. Konflik horizontal yang selalu melibatkan masyarakat yang telah menempati tanah dan bangunan eks kerajaan dengan pihak eks kerajaan terkait tanah eks 
Kerajaan yang akhirnya berakhir sengketa Pengadilan.

Fenomena ketidakadilan substantif terkait kebijakan tanah eks kerajaan dalam Diktum Keempat huruf A UUPA yang berbunyi bahwa "Hak-hak dan wewenangwewenang atas bumi dan air dari Swapraja atau bekas Swapraja (kerajaan) yang masih ada pada waktu mulai berlakunya undangundang ini hapus dan beralih kepada Negara", merupakan ketidakadilan yang dirasakan oleh pihak eks kerajaan mengingat hak atas tanah adalah hak pribadi yang tidak boleh diambil sewenang-wenang. Hal ini terjadi juga karena tidak diberikannya ganti rugi yang layak atas kehilangan hak-hak kenyamanan kehidupan mereka akibat pengambilalihan tanah secara sewenangwenang oleh negara.

Berkaitan dengan banyaknya konflik antara pihak eks kerajaan dengan pemerintah dan warga yang menempati tanah eks kerajaan, maka penulis tertarik untuk meneliti dan menganalisis hasil temuan dalam suatu penelitian yang berjudul "Sengketa Tanah Eks Kerajaan di Kotawaringin Barat Kalimantan Tengah."

\section{Kerangka Teori}

Dalam menganalisis permasalahan dalam penelitian ini, akan digunakan berbagai teori sebagai pisau analisis yaitu teori Konflik, teori Keadilan John Rawl dan teori hukum progresif. Terkait dengan sengketa tanah eks kerajaan, maka kehadiran hukum dalam masyarakat diantaranya adalah untuk mengintegrasikan dan mengkoordinasikan kepentingankepentingan yang berbenturan satu sama lain yang diintegrasikan sedemikian rupa sehingga bisa ditekan sekecil-kecilnya. Kepentingan-kepentingan yang berbenturan itu dikondisikan dengan melindungi kepentingan-kepentingan tersebut.

\section{Hasil Penelitian Terdahulu}

Sejauh pengamatan penulis, dengan melakukan penelusuran kepustakaan, internet dan bentuk publikasi lainnya, belum dijumpai suatu uraian mendalam ataupun penelitian yang memiliki fokus studi mengenai sengketa tanah eks kerajaan baik di Kotawaringin Barat Kalimantan Tengah maupun di daerah lain di Indonesia.

\section{Permasalahan dan Tujuan Penelitian}

Berdasarkan latar belakang di atas, maka permasalahan penelitian ini adalah (1) Bagaimana realitas terjadinya sengketa tanah eks kerajaan di Kotawaringin Barat? (2) Bagaimana solusi untuk mencegah sengketa tanah eks kerajaan di Kotawingin Barat ? Tujuan Peneltian yaitu (1) Untuk mengetahui realitas terjadinya sengketa tanah eks kerajaan di Kotawaringin Barat. (2) Untuk mengetahui solusi mencegah sengketa tanah eks kerajaan di Kotawingin Barat.

\section{B. Metode Penelitian}

Penelitian ini menggunakan metode penelitian kualitatif yang diharapkan dapat ditemukan makna-makna yang tersembunyi dibalik obyek maupun subyek yang akan diteliti. Penelitian dengan pendekatan Socio Legal dengan metode dan teori ilmu sosial tentang hukum untuk membantu peneliti melakukan analisis (Satjipto Rahardjo, 2009). Pendekatan ini dilakukan untuk memahami hukum dalam konteks masyarakatnya (Zamroni, 1992). Pendekatan ini tetap dalam ranah hukum, hanya perspektifnya berbeda. Penelitian ini difokuskan dengan melihat fakta konflik yang berakhir sengketa terkait tanah eks kerajaan di Kotawaringin Barat kalimantan Tengah.

Data dalam penelitian ini diperoleh melalui kegiatan-kegiatan observasi, interview, interpretasi dokumen (teks), serta personal experience. Pada metode penelitian kualitatif, jenis dan cara observasi dipakai sebagai jenis observasi yang dimulai dari cara kerja deskriptif, kemudian observasi berfokus dan pada akhirnya observasi terseleksi (Sanafiah Faisal,1990). Sesuai dengan paradigma penelitian ini, dalam melakukan observasi peneliti akan mengambil posisi sebagai participant observer artinya peneliti menyatu dengan apa yang ditelitinya yang berakibat peneliti dekat dengan obyek yang dikajinya. Peneliti adalah instrumen utama dalam pengumpulan 
data. Indepth interview dilakukan dengan pertanyaan-pertanyaan terbuka (open ended), namun tidak menutup kemungkinan akan dilakukan pertanyaan-pertanyaan tertutup (closed ended) terutama untuk informan yang memiliki banyak informasi tetapi ada kendala dalam mengelaborasi informasinya tersebut( Nasution, 1992).

Teknik untuk menemukan data primer, dilakukan melalui wawancara secara bebas/terbuka atau tak terstruktur secara langsung dengan responden yang ditemui, yang dianggap penting untuk memberikan data dalam penelitian ini. Meskipun terdapat data statistik yang didapat melalui data sekunder maupun wawancara terpadu, tetapi penelitian ini lebih bersifat field research dengan menggunakan pendekatan verstehen atau hermeneutic.

Di samping memanfaatkan dokumentasi dan observasi, pengumpulan data terutama dilakukan melalui wawancara dengan para responden. Kegiatan pengumpulan data meliputi, pertama mencari data primer kemudian data sekunder. Data sekunder adalah data yang telah dikumpulkan dan disistematisir oleh pihak lain dan digunakan juga dalam penelitian ini (David W Stewart, 1984).

\section{Hasil dan Pembahasan}

\section{Realitas Terjadinya Sengketa Tanah Eks Kerajaan Kotawaringin Kalimantan Tengah}

Kerajaan Kotawaringin adalah sebuah kerajaan keturunan Kesultanan Banjar. Kerajaan Kotawaringin terletak di Kalimantan Tengah dengan Istana alNursari yang didirikan pada tahun 1615. Kotawaringin seringpula disebut KutaRingin, karena dalam bahasa Jawa, ringin berarti beringin. Pada masa Kolonial Belanda, Kotawaringin merupakan keadipatian dan sebagai kepala pemerintahan di Kotawaringin adalah Dipati Ngganding. Oleh Dipati Ngganding kemudian diserahkan kepada menantunya Pangeran Dipati Anta Kasuma.

Menurut sejarah Banjar, wilayah Kotawaringin adalah semua desa-desa adat di sebelah barat Banjar (sungai Banjar = sungai Barito) hingga sungai Jelai. Berdasarkan wawancara dengan Agus, seorang kerabat Kasultanan Kotawaringin, pangkalanbun bahwa wilayah Kerajaan Kotawaringin paling barat adalah Tanjung Sambar (Kabupaten Ketapang), batas utara adalah Gunung Sarang Pruya (kabupaten Melawi) dan di timur sampai sungai Mendawai (Tanjung Malatayur) yaitu bagian barat Provinsi Kalimantan Tengah, sedangkan bagian timur Kalimantan Tengah yang dikenal sebagai daerah Biaju (Tanah Dayak) serta daerah pedalaman yang takluk kepadanya tetap di bawah otoritas kepala suku Dayak.

Kotawaringin sempat menjajah negeri Matan dan Lawai atau Pinoh dan menuntut daerah Jelai sebagai wilayahnya. Kotawaringin dalam sejarah Banjar disebutkan sebagai salah satu tanah yang di bawah angin (negeri di sebelah barat) yang telah ditaklukan.

Ibukota Kesultanan Kotawaringin semula berada di Kotawaringin Lama. Pada masa pemerintahan Sultan Imanudin pada tahun 1814 ibukota kesultanan dipindahkan ke Pangkalan Bun dan didirikanlah sebuah Istana Kasultanan Kotawaringin di Pangkalan Bun sebagai pusat pemerintahan.

Setelah Proklamasi Kemerdekaan RI, Kotawaringin menjadi bagian wilayah NKRI dengan status Swapraja/Kawedanan. Selanjutnya berkembang menjadi Kabupaten Daerah Tingkat II Kotawaringin Barat sebagai daerah otonom dengan Pangkalan Bun sebagai ibukota kabupaten.

Kabupaten Kotawaringin Barat (Kobar) adalah salah satu kabupaten di provinsi Kalimantan Tengah. Ibu kota kabupaten ini terletak di Pangkalan Bun. Kabupaten ini memiliki luas wilayah $10.759 \mathrm{~km}^{2}$. Semboyan kabupaten ini adalah Marunting Batu Aji yang artinya Menuju Kejayaan. Wilayah ini terdiri dari 6 (enam) kecamatan, yaitu Kotawaringin Lama, Arut Selatan, Arut Utara, Kumai, Pangkalan Lada dan Pangkalan Banteng.

Pembentukan Kotawaringin Barat diawali dengan terbentuknya 
Provinsi Kalimantan Tengah berdasarkan Keputusan Mendagri Nomor: Up.34/41/24, tanggal 28 Desember 1957 dan Surat Keputusan. Nomor: Des.52/12/2.206, tanggal $22 \quad$ Desember 1959 Tentang Pembagian Kabupaten Kotawaringin Timur dan Kabupaten Kotawaringin Barat.

Menurut Kepala BPN Pangkalanbun Kotawaringin Barat, bahwa setelah keluarnya UUPA, tanah-tanah di Kotawaringin Barat tidak jelas mana yang dinyatakan tanah eks kerajaan dan mana tanah negara serta tanah hak. Semua tanah yang tidak ada bukti hak lama dianggap sebagai Tanah Negara oleh BPN. Sehingga setiap permohonan hak tanah yang dianggap tanah eks kerajaan tidak melalui prosedur pelepasan hak atas tanah. Untuk menghindari konflik yang berkepanjangan sampai terjadi sengketa di Pengadilan, seharusnya ada Surat Keputusan Bupati sebagai Kepala Daerah menetapkan dalam Peraturan Daerah kriteria tanah eks kerajaan yang hapus menjadi tanah negara.

Penafsiran pemerintah (BPN) terhadap Diktum Keempat huruf A UUPA secara positivis-legalistik (teks) tanpa mempertimbangkan aspek sejarah, sosial dan budaya yang ada di masyarakat juga menjadi salah satu pemicu konflik yang berakhir sengketa tanah eks kerajaan di Kotawaringin Barat.

Berdasarkan wawancara dengan Agus Heryanto, Hakim Pengadilan Negeri Pangkalanbun, bahwa salah satu sengketa tanah eks Kerajaan Kotawaringin di Pangkalanbun adalah antara penduduk pendatang (penggugat) yang mengklaim tanah tersebut sebagai kepemilikannya dengan Pemerintah Daerah (Tergugat) terjadi di Pangkalan bun Kalimantan Tengah. Berdasarkan Putusan Pengadilan Nomor 21/Pdt.G/2017/PN PBU, memutuskan bahwa pihak penggugat sebagai yang berhak atas tanah eks Kerajaan. Padahal berdasarkan bukti-bukti yang ada di Kasultanan Kotaringin Barat bahwa pihak penguggat hanya merupakan abdi dalem (pembantu) dari penguasa atau Raja ke VIII Kasultanan Kotawaringan
Barat. Hal ini menunjukkan hakim dalam memutuskan perkara tidak melihat aspek sejarah asal usul beserta riwayat tanah dari Desa disertai bukti-bukti dari Kasultanan sebagai pemegang hak atas tanah tersebut.

Pada tahun 1986, istana Kerajaan Kotawaringin di Pangkalanbun telah terbakar dan oleh Pemerintah Daerah telah dibangun baru dan dinamakan Istana Kuning dan belum masuk dalam Cagar Budaya berdasarkan UU No. 11 tahun 2010. Permasalahan timbul karena pengelola bangunan dan barang-barang peninggalan kasultanan kotaringin seharusnya dari pihak Dinas Pariwisata, akan tetapi dikelola oleh kerabat kasultanan. Permasalahan muncul antar kerabat juga pada Dinas Pariwisata dan Kebudayaan terkait barang-barang kuno yang ada di Istana Kuning tersebut. Barang kuno bisa dialihkan atau dijual karena selama ini belum ada daftar list tentang data barang-barang peninggalan kasultanan kotaringin.

Konflik memuncak saat rumah permaisuri Sultan VII dijadikan rumah jabatan Bupati Pangkalanbun. Rumah tersebut sampai dibakar yang ditenggarai dilakukan oleh para ahli waris Kasultanan Kotawaringin. Meskipun belum sampai ke ranah hukum, akan tetapi sangat meresahkan masyarakat sekitarnya di Pangkalanbun. Pemerintah Daerah sebaiknya segera dibentuk suatu kebijakan yang mengatut tentang tanah eks kerajaan untuk mencegah konflik berkepanjangan dan selalu berakhir sengketa di Pengadilan.

\section{Solusi}

Pemerintah Daerah Kotawaringin Barat menyatakan bahwa berdasarkan nasionalisasi maka hak kerajaan Kotaringin atas tanah Kasultanan menjadi hapus dan beralih kepada Negara Republik Indonesia. Padahal jika kita lihat di dalam UUPA, nasionalisasi hanya terjadi pada tanah-tanah partikelir karena tanah tersebut pemberian Kolonial Belanda pada orang-orang yang berjasa pada pemerintah Belanda. Sedangkan menurut pandangan Badan Pertanahan Nasional Kotawaringin Barat, 
tanah-tanah eks kerajaan hapus karena adanya ketentuan dalam Diktum Keempat huruf A UUPA.

Terjadi konflik yang berkepanjangan sampai berakhir sengketa di Pengadilan disebabkan karena belum diaturnya peraturan pelaksana yang telah diamanatkan Diktum Keempat huruf B UUPA tersebut. Hal ini terjadi karena belum diaturnya prosedur penghapusan tanah eks kerajaan menjadi tanah negara mengakibatkan konflik yang berkepanjangan di Kotawaringin Barat terkait tanah eks Kerajaan Kotaringin. Terlebih belum jelasnya kriteria eks kerajaan dan tanah eks kerajaan membuat konflik semakin panjang sampai saat ini antara pihak eks kerajaan dengan pemerintah daerah.

Negara Indonesia adalah negara hukum yang berbentuk Republik. Kemerdekaan disusun dalam sebuah aturan dasar, yaitu Konstitusi Undang- Undang Dasar Negara Republik Indonesia Tahun 1945 (UUD NRI Tahun 1945). Untuk pertanahan diatur dalam Pasal 33 ayat 3 UUD NRI tahun 1945 yang jelas negara berkuasa atas pertanahan untuk kesejahteraan rakyatnya. Semua hal tentang sistem hukum pertanahan harus sesuai dengan konstitusi.

Berkaitan dengan Kerajaan sebagai lembaga adat karena menyelenggarakan acara adat yang diikuti oleh masyarakat hukum adat di wilayahnya, Konstitusi Undang-Undang Dasar Tahun 1945 dalam Pasal 18 menetapkan bahwa UndangUndang yang mengatur pemerintahan daerah akan memandang dan mengingat hak-hak asal usul daerah yang bersifat istimewa. Hak asal usul yang bersifat istimewa adalah daerah yang mempunyai susunan (pemerintahan asli) seperti misalnya daerah Kerajaan Surakarta. Ketentuan Pasal 18 ini menetapkan masa depan daerah kerajaan harus melihat mengingat asal usul atau sejarahnya.

Tanah dan bangunan eks Kerajaan Kotaringin di Kotawaringin Barat Pangkalanbun belum menjadi cagar budaya sampai sekarang sehingga tidak mendapat dana subsidi dari pemerintah untuk memelihara aset kerajaan tersebut. Akan tetapi mereka tidak mempunyai kekuasaan mengatur hak kepemilikan tanah yang bisa untuk menopang hidup keluarga dan masyarakat sekitarnya. Semua diambil alih oleh Pemerintah Daerah baik dalam pengelolaan maupun hak atas bangunannya.

Realitas menunjukkan belum ada upaya pemerintah daerah dan pihak Badan Pertanahan Nasional (BPN) untuk menyelesaikan konflik-konflik yang berakhir sengketa tanah yang terjadi di Kotawaringin Barat. Seharusnya para pihak mengadakan pertemuan untuk menghasilkan kesepakatan yang dituangkan dalam perjanjian. Perjanjian terkait tanah-tanah eks kerajaan yang akan dilepaskan oleh pihak kerajaan untuk kepentingan pemerintah daerah atau supaya bisa digunakan oleh warga masyarakat yang secara fisik menguasai tanah tersebut.

Menurut Muasjidin sebagai kerabat eks Kerajaan Kotaringin, bahwa pemerintah daerah tidak mengakui eks Kerajaan Kowatringin sebagai lembaga adat, dimana selama ini masyarakat adat di Kotawaringin Barat masih mengikuti acara tradisi adat budaya eks kerajaan Kotaringin dan mengikuti ritual adat yang diadakan Kerajaan.

Eks Kerajaan sebagai lembaga adat membutuhkan pembiayaan untuk penyelenggaraan urusan adatnya yaitu upacara-upacara adat, harus membayar gaji pegawai, sentana, serta pemeliharaan bangunan-bangunan kerajaan dan makam leluhur, membutuhkan biaya yang tidak sedikit. Semua aset tanah dan bangunan diluar keraton milik eks kerajaan dan Mangkunegaran telah diambil alih pemerintah tanpa kompensasi apapun. Hal ini jelas melanggar Pasal $28 \mathrm{H}$ UUD NRI 1945 yang berbunyi (4) Setiap orang berhak mempunyai hak milik pribadi dan hak milik tersebut tidak boleh diambil alih secara sewenang-wenang oleh siapa pun.

Solusi untuk mencegah konflik yang berkepanjangan sampai berakhir sengketa di Pengadilan yaitu selama belum terbentuk PP yang diamanatkan dalam Diktum Keepat 
huruf A UUPA, pihak Pemerintah Daerah tidak melakukan pendaftaran tanah eks kerajaan Kotawaringin sebelum ada pelepasan hak dari Kasultanan Kotawaringin sesuai dengan apa yang diatur dalam UUPA dan pihak Badan Pertanahan Nasional tidak melakukan pendaftaran tanah eks kerajaan Kotawaringin Kalimantan Tengah tanpa ada pelepasan hak dari Kasultanan, untuk menghindari konflik yang berakhir sengketa di Pengadilan.

\section{Simpulan}

Berpijak pada analisis data yang telah dipaparkan dalam Bab sebelumnya, maka dapat ditarik simpulan sebagai berikut :

1. Realitas Sengketa tanah eks Kerajaan Kotaringin terjadi karena :

a. Ketentuan dalam Diktum Keempat huruf $A$ dan B UUPA tidak dilaksanakan secara konsisten di lapangan.

b. Kebijakan pemerintah ( BPN) masih berorientasi pada keadilan prosedural, yang seringkali tidak mencerminkan keadilan yang sebenarnya (keadilan substantif).

c. Penafsiran pemerintah (BPN) terhadap Diktum Keempat huruf A UUPA secara positivis-legalistik (teks) tanpa mempertimbangkan aspek sejarah, sosial dan budaya yang ada di masyarakat.

d. Tidak diatur secara jelas pengertian kerajaan, eks kerajaan juga tanahtanah eks kerajaan dalam suatu kebijakan sebagai peraturan pelaksana yang telah diamanatkan dalam Diktum Keempat huruf B UUPA yaitu berupa Peraturan Pemerintah.

e. Tidak ada kejelasan pengaturan mengenai pengaturan bentuk dan kriteria ganti rugi dan atau kompensasi atas penghapusan tanah kerajaan dan tanah eks kerajaan.

Konflik-konflik yang berakhir sengketa di Pengadilan dipandang sebagai fenomena, bahwa kebijakan tanah eks kerajaan pada Diktum
Keempat huruf B UUPA yang berbunyi "Hal-hal yang bersangkutan dengan ketentuan dalam huruf $\mathrm{A}$ di atas diatur lebih lanjut dengan Peraturan Pemerintah", belum dilaksanakan oleh pemerintah sehingga prosedur pelaksanaan penghapusan tanah eks Kerajaan menjadi tanah negara yang disebutkan pada Diktum Keempat huruf A UUPA belum ada. Sehingga banyak tanah eks kerajaan diambilalih tanpa melalui prosedur benar yang melanggar hak asasi manusia yang diatur dalam Konstitusi UUDN RI Tahun 1945 dan Pancasila. Hal ini berarti kebijakan tanah eks kerajaan belum mencerminkan keadilan bagi pihak eks kerajaan di Indonesia.

2. Solusi Mencegah Sengketa Tanah eks Kerajaan Kotaringin di Kotawingin Barat.

Berdasarkan Konstitusi UUD NRI Tahun 1945 sebagaimana dinyatakan dalam Pasal $28 \mathrm{H}$ bahwa hak milik pribadi tidak boleh diambil secara sewenang-wenang. Hal-hal tersebut tidak diperhatikan oleh pihak pemerintah, sehingga putusan BPN dan Pemerintah Daerah tidak mencerminkan keadilan bagi warga yang berhak atas tanah. BPN yang berpandangan progresif yang bisa melihat hukum tidak sebatas peraturan semata.Dengan demikian, metode yang bisa dipakai untuk mewujudkan keadilan substansial, yakni metode rule breaking yang merupakan karakteristik dalam hukum progresif. Pihak BPN harus berani tidak melakukan pendaftaran tanah eks kerajaan Kotawaringin karena tidak ada pelepasan hak dari pihak Kasultanan sebagai pemegang hak atas tanah. Disini lah aksi rule breaking yang dilakukan BPN untuk menegakkan keadilan karena belum terbentuknya PP yang diamanatkan Diktum Keempat huruf B UUPA sehingga proses pendaftaran tanah harus melalui pelepasan hak atas tanah dari pihak pemegang hak atas tanah. 
Tanah sebagai hak dasar setiap orang, keberadaannya dijamin di dalam Konstitusi Undang-Undang Dasar Negara Republik Indonesia Tahun 1945, oleh karena itu Pemerintah segera melaksanakan amanat Diktum keempat huruf B UUPA untuk membuat kebijakan mengenai eks tanah kerajaan berupa Peraturan Pemerintah yang mengakomodasi kepentingan pihak kerajaan, pemerintah kota/kabupaten dan masyarakat.

Solusi kedua yaitu perlu dibuatkan kebijakan dalam bentuk Peraturan Daerah oleh Pemerintah Daerah yang khusus mengatur mengenai tanah eks kerajaan yang ditempati masyarakat adat eks Kerajaan dan masih terjaga upacara adat budaya (kepercayaan) didalamnya sebagai Masyarakat Hukum Adat. Sehingga tidak menyimpang dari kebijakan yang akan diatur dalam Peraturan Pemerintah.

\section{DAFTAR PUSTAKA}

\section{BUKU}

Abd, A'la, 2010, Pembumian Keadilan Substantif, Semarang : Jawa Pos.

Akhamad, Bendara, 2011, Lintasan Sejarah Sumenep dan Asta Tinggi beserta Tokoh didalamya, Sumenep: Barokah.

Ali, Achmad, 1998, Menjelajahi Kajian Empiris Terhadap Hukum, Jakarta : Yarsif Watampone. 2010, Menguak Teori Hukum dan Teori Peradilan Vol.1, Jakarta ; Kencana.

Ali, As'ad Said, 2012, Tinjauan Yuridis Terhadap Sarana Hukum Sebagai Pengaman Ideologi Dan Dasar Negara, Pidato Penganugerahan Gelar Doctor Honoris Causa Dalam Bidang Hukum, Semarang : Universitas Diponegoro.

Alloott, Antony, 1981, The Effectiveness of Law, dalam Valparaiso, Winter : University Law Review.

Alwasilah, Chedar, 2002, Pokoknya Kualitatif, Dasar-dasar Merancang dan Melakukan Penelitian Kualitatif, Jakarta : Pustaka Jaya.
Anshori, Abdul Ghofur, 2006, Filsafat Hukum, Yogyakarta : Gadjah Mada University Press.

Arto, A. Mukti, 2001, Mencari Keadilan, Kritik, danSolusi Terhadap Praktik Peradilan Perdata di Indonesia, Yogyakarta: Pustaka Pelajar.

Bakir, Herman, 2007, Filsafat Hukum, Bandung : Refika Aditama.

Berry, David, 2003, The Prinsiples of Sociology atau Pokok-Pokok PikiranDalam Sosiologi, Jakarta : Raja Grafindo Persada.

Budiman, Arief, 1989, Sistem Perekonomian pancasila dan Ideologi Ilmu Sosialdi Indonesia, Jakarta : Gramedia.

\section{PERATURAN PERUNDANG- UNDANGAN}

UU Nomor 5 Tahun 1960 tentang Peraturan Dasar Pokok-Pokok Agraria.

UU Nomor 32 tahun 2004 tentang Pemerintahan Daerah.

PP No. 224 Tahun 1961 tentang Pelaksanaan Pembagian Tanah dan Pemberian Ganti Kerugian.

PP No. 38 Tahun 1963 tentang Penunjukan Badan-Badan Hukum yang Dapat Mempunyai Hak Milik Atas Tanah. 